\title{
XXXV. On simultaneous thunder-storms
}

\section{Dr. T. Forster}

To cite this article: Dr. T. Forster (1822) XXXV. On simultaneous thunder-storms, Philosophical Magazine Series 1, 60:293, 195-196, DOI: $10.1080 / 14786442208652819$

To link to this article: http://dx.doi.org/10.1080/14786442208652819

曲 Published online: 29 Jul 2009.

Submit your article to this journal $\pi$

III Article views: 2

Q View related articles $₫$ 
be observed that the formula I have given would bring out results conformable to the indications of an air thermometer. This is of little importance in temperatures beneath $212^{\circ}$; but in very high ranges, in which at least one experiment ought to be made, it would be of vital consequence.

$$
\begin{aligned}
& \text { I am, dear sirs, } \\
& \text { Your obedient humble servant, }
\end{aligned}
$$

J. Herapath.

\section{On simultancous Thunder-Siorms. By Dr.T. Fonster.}

\section{To the Editors of the Philosophical Magazine and Journal.}

Hartwell, Sept. 3, 1822.
Genthemen,-I have already stated my opinion that the formation of thunder-storms, and other electrical phænomena, frequently took place simultaneously in very distant parts of the atmosphere. I have lately had an opportunity of confirming this opinion, and of witnessing several of the most violent instances of storms which have ever been recorded in the memory of the inhabitants of those districts where they occurred; and of comparing them with similar phænomena in distant parts of Europe.

On Monday evening, July the 29th, while travelling from Gex to Nyon, on the Lake of Geneva, we were overtaken by one of the most violent storms I ever remember to have seen: it formed very rapidly, for at half-past four o'clock the atmosphere was clear. I observed however that on descending Mount Jura, the Alps (which form a beautiful back-ground to the view of the lake below) were intersected with clouds: the cirrostratus seemed to unite the summits of the range of mountains by forming long lines of cloud stretched across from one hill to another, while the more elevated ground of Mont Blanc was involved in eumulostratus. The air very suddenly became totally obscure, and before 5 o'clock a violent shower of rain and hail came down in torrents, accompanied by thunder and lightning: it cleared off very suddenly, but as quickly returned again; and for the space of nearly an hour there was scarcely an interval of two minutes between the most vivid flashes of lightning. I distinctly noticed the two sorts mentioned by M. Van Mons; namely, the fulguration followed quickly by a short and loud clap; and the fulmination followed at a longer interval by rolling thunder. The fulguration or forked lightning darted into the lake from several distant portions of cloud at once, and was at times of a bright B b 2 
blue colour. By 8 o'clock the storm subsided: on the following day, July 30th, after a bright morning, a still more violent storm occurred very suddenly in the neighbourhood of Lausanne: its formation was prodigiously rapid, so that in five minutes after bright sunshine, a torrent of rain and hail fell, which desolated many of the vineyards, and the thunder and lightning scarcely ceased during the space of several following hours. In travelling from Lausanne to Vevai, we were forced to alight from the carriage and take refuge in a house by the road side. At Belle Airo near Vevai, the residence of $M$. Bart. Huber, the hail is said to have descended in stones above an inch in diameter, and to have been so destructive that scarcely one entire bunch of grapes remained on the vines after it was over. I heard of a few persons being killed and part of a house destroyed in the neighbourhood. As I travelled home along the Rhine, by way of Bâle and Strasbourg, into Holland, I found, by making inquiries, that contemporaneous storms of similar violence had been witnessed throughout a most extensive tract of country, both in France and Germany. At the Hague three men were killed, and a fourth was killed while travelling on the road towards Haerlem. At Dunkirk the lofty tower of the church was struck, and the sentinel placed at the top was attacked by the lightning and rendered senseless for some time, though he eventually recovered. I heard also of several flocks of sheep and other cattle being destroyed by the electric fluid. At Bridgenorth in England, on Sunday the 28th of July (being the day previous to the great storm at Nyon), the lightning did considerable mischief-killed one person, and a great many sheep; and I have received several similar accounts from other parts; thus proving-not only a disposition in the air to produce thunder-storms at very distant places, but proving also that they occurred in distant places with the same violent and mischievous character.

I shall be obliged by any accounts of the said storms made by your correspondents in different places, and of the state of the instruments of ineteorology at the time, and communicated throngh your Journal: and I have the honour to remain

Your most obedient

T. ForSTER.

P.S. The thermometer at Lausanne on the 30th of July stood at 34 of Fahrenheit at noon. 